Editorial

\title{
On the road to sophisticated education and science
}

\section{Editorial}

I saw him in the marble and carved until I set him free.

\section{Michelangelo}

Nowadays, science, engineering and humanities are not intended for a narrow, specialized group of scholars, implementers and innovators. They all dream of future, better future. The future of science, engineering and humanities is and will be decided by the most diverse research teams, teams that are not limited to the exact circle of scientists and scholars. Let me call them people outside the box. A person of that kind is characterized by a fresh, unrestricted experience in a single discipline, and the one that can articulate new ideas. This person does not even have to be a so-called scientist or scholar. Certain times of the glasses and the eye have gone forever. Young generations should be educated for active, everyday collaboration then. They should know how to get in touch, how to collaborate all together. It is a must for today. Universities of modern countries distinguish that matter since many decades: Stanford University ${ }^{1}$, Aalborg University ${ }^{2}$, Aalto University ${ }^{3}$, Porto Polytechnic ${ }^{4}$, to mention only a few of them. They see that a good academic or research project need varied specialists such as designers, business people, scientists, scholars, specialists in disciplines not limited to the main area of a project's horizon. That way of thinking, that aspects of science, engineering and humanities academic education, have been appreciated at the Warsaw University of Technology (Warsaw, Poland) for few years ago. The authorities of University have called the Rector's Team for innovative forms of education. This Team is Warsaw University of Technology creativity booster. Souls and minds of its members are full of creative, innovative and visionary, yet half-baked ideas. And they would like to share mentioned ideas and exchange their points of view with people from around the world. The members of the Rector's Team for innovative forms of education are highly diverse and, at the same time, fully complementary. This contributes to their openness for world-wide cooperation. They believe in learning by doing that is why they implement problem-based learning methodology combined with design thinking ${ }^{5}$ and other methods of education. They want to have an impact on innovative education and are not afraid of new challenges. They dream of a modern, innovative university, interdisciplinary teams of creative students and fulfilled academic teachers. The fact is that the Warsaw University of Technology takes first place among technical universities in Poland, but they are focused on constant improvement, to become better than themselves from yesterday. They also dream of future. So as you do, I am sure of that.

'https://dschool.stanford.edu, accesssed on-line: August $2^{\text {nd }}, 2017$.

${ }^{2} \mathrm{http}: / / \mathrm{www} . p b l . a a u . d k$, accesssed on-line: August $2^{\text {nd }}, 2017$.

${ }^{3} \mathrm{https}: / /$ designfactory.aalto.fi, accesssed on-line: August 2 ${ }^{\text {nd }}, 2017$.

${ }^{4} \mathrm{https} / / /$ www.pdf.ipp.pt, accesssed on-line: August 2nd, 2017.

${ }^{5}$ Design thinking in education typically takes three forms: helping school administrators solve institution-based problems, aiding educators to develop more creative lesson plans, and engendering design thinking skills in students.
Volume I Issue 2 - 2017

Mariusz Kostrzewski

Faculty of Transport, Warsaw University of Technology, Poland

Correspondence: Mariusz Kostrzewski, Faculty of Transport, Warsaw University of Technology, Poland,

Email markos@wt.pw.edu.pl

Received: August 02, 2017| Published: August 04, 2017

Some people say that there is no „I" in ,team”. It is only part of the true. Every other member is unique „I" in the Team as well. All of „I" define the Team. I may say, I am proud member of the Rector's Team for innovative forms of education. As Assistant Professor at Warsaw University of Technology, I have great opportunity to combine all my abilities. I implement innovative forms of education at Warsaw University of Technology within which I create short animated pictures and execute prototypes together with students. In everyday activities, I consciously believe in the significance of Japanese art, which by transmitting artistic, artisan and technical values, serves the everyday, mundane life. The same as science, engineering and humanities. All of them are no more l'art pour l'art (Fr. art for art) and do not occur separately. They serve our generation and future ones. The motto of the editorial shines my aim, never ending one. Humanity, our World need more people like us for better future. People like you. That is why we, and now I mean Editors of the Journal, are delighted to publish your review articles, short communications, case reports, case studies, mini-reviews, opinions, letter to editors and especially research papers of innovative research teams connected to fields which will be enlightening the scientific community. The Journal covers all the aspects of bionic science and engineering including fundamental understandings of animals and plants for bionic engineering, such as locomotion and behaviors of animals, structures, composites, morphology and physical properties of plants and natural materials, applications of such understandings in engineering, technology and designs. As Associate Editor, I believe we will do our best to meet the needs of even the most critical consumer of media messages about science.

\section{Acknowledgements}

None.

\section{Conflict of interest}

Author declares that there is no conflict of interest. 